\title{
Late Cenozoic Climate History of the Ross Embayment from the AND-1B Drill Hole: Culmination of Three Decades of Antarctic Margin Drilling
}

\author{
T. R. Naish,$^{1,2}$ R. D. Powell, ${ }^{3}$ P. J. Barrett, ${ }^{1}$ R. H. Levy,${ }^{4}$ S. Henrys, ${ }^{1}$ G. S. Wilson,${ }^{5}$ L. A. Krissek, ${ }^{6}$ F. Niessen, ${ }^{7}$ \\ M. Pompilio, ${ }^{8}$ J. Ross,${ }^{9}$ R. Scherer, ${ }^{3}$ F. Talarico, ${ }^{10}$ A. Pyne, ${ }^{1}$ and the ANDRILL-MIS Science team ${ }^{11}$
}

\begin{abstract}
Because of the paucity of exposed rock, the direct physical record of Antarctic Cenozoic glacial history has become known only recently and then largely from offshore shelf basins through seismic surveys and drilling. The number of holes on the continental shelf has been small and largely confined to three areas (McMurdo Sound, Prydz Bay, and Antarctic Peninsula), but even in McMurdo Sound, where Oligocene and early Miocene strata are well cored, the late
\end{abstract}

\footnotetext{
${ }^{1}$ Antarctic Research Centre, Victoria University of Wellington, Wellington, New Zealand (t.naish@gns.cri.nz, peter.barrett@vuw.ac.nz, alex. pyne@vuw.ac.nz).

${ }^{2}$ Geological and Nuclear Sciences, Lower Hutt, New Zealand (t.naish@ gns.cri.nz, s.henrys@gns.cri.nz).

${ }^{3}$ Department of Geology and Environmental Geosciences, Northern Illinois University, DeKalb, IL, USA (ross@geol.niu.edu).

${ }^{4}$ ANDRILL Science Management Office, University of NebraskaLincoln, 126 Bessey Hall, Lincoln, NE 68588-0341, USA (rlevy2@unl. edu).

${ }^{5}$ Department of Geology, University of Otago, PO Box 56, Dunedin, New Zealand (gary.wilson@otago.ac.nz).

${ }^{6}$ Department of Geosciences, The Ohio State University, Columbus, OH, USA (krissek@mps.ohio-state.edu).

${ }^{7}$ Department of Marine Geophysics, Alfred Wegener Institute, Postfach 1201 61, Columbusstrasse, D-27515, Bremerhaven, Germany (fniessen@ awi-bremerhaven.de).

${ }^{8}$ Istituto Nazionale di Geofisica e Vulcanologia, Via della Faggiola, 32, ${ }^{9} \mathrm{I}-56126$ Pisa, Italy (pompilio@ pi.ingv.it).

New Mexico Geochronology Research Laboratory, Socorro, NM 87801, USA (jirhiker@nmt.edu).

${ }^{10}$ Università di Siena, Dipartimento di Scienze delle Terra,Via Laterina 8, I-53100 Siena, Italy (talarico@unisi.it).

${ }^{11}$ See http://www.andrill.org/support/references/appendixc.html.
}

Cenozoic is poorly known and dated. The latest Antarctic geological drilling program, ANDRILL, successfully cored a 1285-m-long record of climate history spanning the last 13 m.y. from subsea-floor sediment beneath the McMurdo Ice Shelf (MIS), using drilling systems specially developed for operating through ice shelves. The cores provide the most complete Antarctic record to date of ice-sheet and climate fluctuations for this period of Earth's history. The $>60$ cycles of advance and retreat of the grounded ice margin preserved in the AND-1B record the evolution of the Antarctic ice sheet since a profound global cooling step in deep-sea oxygen isotope records $\sim 14$ m.y.a. A feature of particular interest is a 90-m-thick interval of diatomite deposited during the warm Pliocene and representing an extended period ( 200,000 years) of locally open water, high phytoplankton productivity, and retreat of the glaciers on land.

\section{HISTORICAL OVERVIEW}

The remarkable late Cenozoic record of glacial history in the Ross Embayment recovered in late 2006 by the ANDRILLMIS Project is the culmination of work begun over three decades ago to document and understand the more recent glacial history of Antarctica by drilling close to the margin. Ironically, although the last 3 million years of Earth's climate is often said to be the best studied interval of the Cenozoic, the contribution of Antarctic ice volume changes is the most poorly understood. Until this most recent hole was drilled, the middle Cenozoic record was better known from several holes in both the McMurdo region and Prydz Bay (Table 1). This is in general because the older strata were exposed closer to the coast through basin uplift, where younger strata had been removed by Neogene erosion, but also because in offshore basins glacial debris from the last glacial advance 
TABLE 1 Antarctic Coastal and Continental Shelf Rock-Drilling Sites, 1973 to 2006

\begin{tabular}{|c|c|c|c|c|c|c|c|c|c|}
\hline Project & Year & Site & Lat & Long & $\begin{array}{c}\text { Elev }(+) \text { or } \\
\text { Wat.Dep (-) }\end{array}$ & $\begin{array}{l}\text { Depth } \\
\text { cored }\end{array}$ & $\begin{array}{c}\% \\
\text { recov. }\end{array}$ & Oldest core & Reference \\
\hline \multicolumn{10}{|l|}{ Ross Sea } \\
\hline \multirow[t]{4}{*}{ DSDP 28} & 1973 & 270 & $77^{\circ} 26^{\prime} \mathrm{S}$ & $178^{\circ} 30^{\prime} \mathrm{W}$ & $-634 m$ & $423 \mathrm{~m}$ & $62 \%$ & gneiss - E Paleozoic & \multirow[t]{4}{*}{ Hays, Frakes et al., 1975} \\
\hline & & 271 & $77^{\circ} 26^{\prime} \mathrm{S}$ & $178^{\circ} 30^{\prime} \mathrm{W}$ & $-562 m$ & $233 \mathrm{~m}$ & $7 \%$ & diamict clasts - E Pliocene & \\
\hline & & 272 & $77^{\circ} 26^{\prime} \mathrm{S}$ & $178^{\circ} 30^{\prime} \mathrm{W}$ & $-629 m$ & $439 \mathrm{~m}$ & $37 \%$ & diamict - E Miocene & \\
\hline & & 273 & $77^{\circ} 26^{\prime} \mathrm{S}$ & $178^{\circ} 30^{\prime} \mathrm{W}$ & $-491 \mathrm{~m}$ & $333 \mathrm{~m}$ & $25 \%$ & diamict - E Miocene & \\
\hline \multicolumn{10}{|c|}{ McMurdo Sound area - onshore } \\
\hline \multirow[t]{6}{*}{ DVDP } & 1973 & 1 & $77^{\circ} 50^{\prime} \mathrm{S}$ & $166^{\circ} 40^{\prime} \mathrm{E}$ & $67 \mathrm{~m}$ & $201 \mathrm{~m}$ & $98 \%$ & basalt - L Quat & \multirow[t]{3}{*}{ Kyle, 1981} \\
\hline & 1973 & 2 & $77^{\circ} 51^{\prime} \mathrm{S}$ & $166^{\circ} 40^{\prime} \mathrm{E}$ & $47 \mathrm{~m}$ & 179 m & $96 \%$ & basalt - L Quat & \\
\hline & 1973 & 3 & $77^{\circ} 51^{\prime} \mathrm{S}$ & $166^{\circ} 40^{\prime} \mathrm{E}$ & $48 \mathrm{~m}$ & $381 \mathrm{~m}$ & $90 \%$ & basalt - L Quat & \\
\hline & 1974 & 10 & $77^{\circ} 35^{\prime} \mathrm{S}$ & $163^{\circ} 31^{\prime} \mathrm{E}$ & $3 \mathrm{~m}$ & $182 \mathrm{~m}$ & $83 \%$ & diamict - L Miocene & \multirow[t]{3}{*}{ Powell, 1981} \\
\hline & 1974 & 11 & $77^{\circ} 35^{\prime} \mathrm{S}$ & $163^{\circ} 25^{\prime} \mathrm{E}$ & $80.2 \mathrm{~m}$ & $328 \mathrm{~m}$ & $94 \%$ & diamict - L Miocene & \\
\hline & 1974 & 12 & $77^{\circ} 38^{\prime} \mathrm{S}$ & $162^{\circ} 51^{\prime} \mathrm{E}$ & $75.1 \mathrm{~m}$ & $185 \mathrm{~m}$ & $98 \%$ & migmatite - E Paleozoic & \\
\hline \multicolumn{10}{|c|}{ McMurdo Sound area - offshore } \\
\hline DVDP 15 & 1975 & 15 & $77^{\circ} 26^{\prime} \mathrm{S}$ & $164^{\circ} 23^{\prime} \mathrm{E}$ & $-122 \mathrm{~m}$ & $62 \mathrm{~m}$ & $52 \%$ & black sand - E Pleist & Barrett and Treves, 1981 \\
\hline MSSTS & 1979 & 1 & $77^{\circ} 34^{\prime} \mathrm{S}$ & $163^{\circ} 23^{\prime} \mathrm{E}$ & $-195 \mathrm{~m}$ & $230 \mathrm{~m}$ & $62 \%$ & mudstone - L Oligocene & Barrett, 1986 \\
\hline CIROS & 1986 & 1 & $77^{\circ} 05^{\prime} \mathrm{S}$ & $164^{\circ} 30^{\prime} \mathrm{E}$ & $-197 m$ & $702 \mathrm{~m}$ & $98 \%$ & boulder congl - L Eocene & Barrett, 1989 \\
\hline CIROS & 1984 & 2 & $77^{\circ} 41^{\prime} \mathrm{S}$ & $163^{\circ} 32^{\prime} \mathrm{E}$ & $-211 \mathrm{~m}$ & $168 \mathrm{~m}$ & $67 \%$ & gneiss - E Paleozoic & Barrett and Hambrey, 1992 \\
\hline \multirow{3}{*}{ CRP } & 1997 & 1 & $77^{\circ} 00^{\prime} \mathrm{S}$ & $163^{\circ} 45^{\prime} \mathrm{E}$ & $-154 m$ & $148 \mathrm{~m}$ & $86 \%$ & diamict - E Miocene & CRST, 1998 \\
\hline & 1998 & 2 & $77^{\circ} 00^{\prime} \mathrm{S}$ & $163^{\circ} 43^{\prime} \mathrm{E}$ & $-178 m$ & $624 \mathrm{~m}$ & $95 \%$ & mudstone - Oligocene & CRST, 1999 \\
\hline & 1999 & 3 & $77^{\circ} 00^{\prime} \mathrm{S}$ & $163^{\circ} 43^{\prime} \mathrm{E}$ & $-295 \mathrm{~m}$ & $939 \mathrm{~m}$ & $97 \%$ & sandstone - Devonian & CRST, 2000 \\
\hline ANDRILL & 2006 & 1 & $77^{\circ} 55^{\prime} \mathrm{S}$ & $167^{\circ} 01^{\prime} \mathrm{E}$ & $-840 \mathrm{~m}$ & $1285 \mathrm{~m}$ & $98 \%$ & basalt - E Miocene & Naish et al., 2006 \\
\hline \multicolumn{10}{|l|}{ Prydz Bay } \\
\hline \multirow[t]{5}{*}{ ODP 119} & 1988 & 739 & $67^{\circ} 17^{\prime} \mathrm{S}$ & $75^{\circ} 05^{\prime} \mathrm{E}$ & $-412 m$ & $487 \mathrm{~m}$ & $34 \%$ & diamict - L Eo-E Oligocene & \multirow{5}{*}{$\begin{array}{l}\text { Barron, Larsen et } \\
\text { al., } 1988\end{array}$} \\
\hline & 1988 & 740 & $68^{\circ} 41^{\prime} \mathrm{S}$ & $76^{\circ} 43^{\prime} \mathrm{E}$ & $-808 \mathrm{~m}$ & $226 \mathrm{~m}$ & $32 \%$ & red beds - ?Triassic & \\
\hline & 1988 & 741 & $68^{\circ} 23^{\prime} \mathrm{S}$ & $76^{\circ} 23^{\prime} \mathrm{E}$ & $-551 \mathrm{~m}$ & $128 \mathrm{~m}$ & $26 \%$ & sandst, siltst -?E Cretaceous & \\
\hline & 1988 & 742 & $67^{\circ} 33 \mathrm{~S}$ & $75^{\circ} 24^{\prime} \mathrm{E}$ & $-416 m$ & $316 \mathrm{~m}$ & $53 \%$ & mudst, diamict - ?Eo-Olig & \\
\hline & 1988 & 743 & $66^{\circ} 55^{\prime} \mathrm{S}$ & $74^{\circ} 42^{\prime} \mathrm{E}$ & $-989 m$ & $97 \mathrm{~m}$ & $22 \%$ & diamict - Pleistocene & \\
\hline ODP 188 & 2000 & 1166 & $67^{\circ} 42^{\prime} \mathrm{S}$ & $74^{\circ} 47^{\prime} \mathrm{E}$ & $-475 \mathrm{~m}$ & $381 \mathrm{~m}$ & $19 \%$ & claystone - L Cretaceous & $\begin{array}{l}\text { O'Brien, Cooper, Richter et } \\
\text { al., } 2001\end{array}$ \\
\hline \multicolumn{10}{|c|}{ Antarctic Peninsula } \\
\hline \multirow[t]{6}{*}{ ODP 178} & 1998 & 1097 & $66^{\circ} 24^{\prime} \mathrm{S}$ & $70^{\circ} 45^{\prime} \mathrm{W}$ & $-563 m$ & $437 \mathrm{~m}$ & $14 \%$ & diamict - E Pliocene & \multirow[t]{6}{*}{$\begin{array}{l}\text { Barker, Camerlenghi, Acton et } \\
\text { al., } 1999\end{array}$} \\
\hline & 1998 & 1098 & $64^{\circ} 52^{\prime} \mathrm{S}$ & $64^{\circ} 12^{\prime} \mathrm{W}$ & $-1010 \mathrm{~m}$ & $47 \mathrm{~m}$ & $99 \%$ & mud - Holocene & \\
\hline & 1998 & 1099 & $64^{\circ} 57^{\prime} \mathrm{S}$ & $64^{\circ} 19^{\prime} \mathrm{W}$ & $-1400 \mathrm{~m}$ & $108 \mathrm{~m}$ & $102 \%$ & mud - Holocene & \\
\hline & 1998 & 1100 & $66^{\circ} 53^{\prime} \mathrm{S}$ & $65^{\circ} 42^{\prime} \mathrm{W}$ & $-459 \mathrm{~m}$ & $111 \mathrm{~m}$ & $5 \%$ & diamict - Pleistocene & \\
\hline & 1998 & 1102 & $66^{\circ} 48^{\prime} \mathrm{S}$ & $65^{\circ} 51^{\prime} \mathrm{W}$ & $-431 \mathrm{~m}$ & $15 \mathrm{~m}$ & $6 \%$ & diamict - Pleistocene? & \\
\hline & 1998 & 1103 & $64^{\circ} 00^{\prime} \mathrm{S}$ & $65^{\circ} 28^{\prime} \mathrm{W}$ & $-494 m$ & $363 \mathrm{~m}$ & $12 \%$ & diamict - L Miocene & \\
\hline SHALDRIL & 2005 & 1 & $62^{\circ} 17^{\prime} \mathrm{S}$ & $58^{\circ} 45^{\prime} \mathrm{W}$ & $-488 m$ & $108 \mathrm{~m}$ & $87 \%$ & mud - L Pleistocene & \multirow{5}{*}{$\begin{array}{l}\text { http://shaldril.rice.edu/ } \\
\text { Anderson et al., } 2007\end{array}$} \\
\hline \multirow[t]{4}{*}{ SHALDRIL } & 2006 & 3 & $63^{\circ} 51^{\prime} \mathrm{S}$ & $54^{\circ} 39^{\prime} \mathrm{W}$ & $-340 \mathrm{~m}$ & $20 \mathrm{~m}$ & $32 \%$ & mudst - L Eo/E Oligocene & \\
\hline & 2006 & 5 & $63^{\circ} 15^{\prime} \mathrm{S}$ & $52^{\circ} 22^{\prime} \mathrm{W}$ & $-506 m$ & $23 \mathrm{~m}$ & $40 \%$ & muddy sand - mid Miocene & \\
\hline & 2006 & 6 & $63^{\circ} 20^{\prime} \mathrm{S}$ & $52^{\circ} 22^{\prime} \mathrm{W}$ & $-532 m$ & $21 \mathrm{~m}$ & $\mathrm{n} / \mathrm{a}$ & muddy sand - E Pliocene & \\
\hline & 2006 & 12 & $63^{\circ} 16^{\prime} \mathrm{S}$ & $52^{\circ} 50^{\prime} \mathrm{W}$ & $-442 \mathrm{~m}$ & $4 \mathrm{~m}$ & $64 \%$ & mudst - Oligocene & \\
\hline
\end{tabular}


prevented penetration and recovery of the older record from gravity coring (Anderson, 1999). Plainly deep-drilling technology was required from an appropriate location. Here we summarize the history and rationale behind this successful outcome.

By the early 1970s the International Geophysical Year (1956-1958) had already resulted in a vast increase in knowledge of rock types, ages, and history of the continent itself (Bushnell and Craddock, 1970), but the history of its ice sheet was still a mystery. This changed in early 1973 with the voyages of the Glomar Challenger to the South Indian Ocean and Ross Sea (Leg 28) (Hayes et al., 1975) and the Tasman Sea and Southwest Pacific Ocean (Leg 29) (Kennett et al., 1974). The first of these cruises showed that the Antarctic ice sheet, which had previously been seen as a Quaternary feature, had been in existence since at least the Oligocene. The second yielded the first oxygen isotope measurements on deep-sea calcareous microfossils, providing the first evidence of dramatic ocean cooling and global ice volume increase at the Eocene-Oligocene boundary (Shackleton and Kennett, 1974).

The 1970s was also a period in which detailed paleontological and chronological studies of cores from continuously deposited deep-sea sediments displaced the long-held view of four major Quaternary glaciations (Flint, 1971), showing much more frequent cycles of climate, ice volume, and sea level in the late Quaternary (Hays et al., 1976) in response to variations in Earth's orbital parameters calculated by Milankovitch. How far back in time these should be evident was not clear, but there seemed no reason why they should not have influenced the Antarctic ice sheet from the time of its inception.

While deep ocean sediments were useful for their continuous record of past ocean chemistry, providing an ice volume-temperature signal, they could not provide information on the extent of ice or regional climate in the high latitudes. This could only come out of sediment cores from the Antarctic margin, where the direct influence of ice advance and retreat (and perhaps also sea-level fall and rise) could be obtained.

In the early 1970s two drilling platforms were available. The Glomar Challenger operated by the Deep Sea Drilling Project and a land-based system put together for the Dry Valley Drilling Project, an initiative of the United States, Japan, and New Zealand to explore the late Cenozoic history of the McMurdo Dry Valleys (Smith, 1981). Over the next three decades both of these platforms (and their successors) ran in parallel (Table 1, Figure 1) with varying degrees of success.

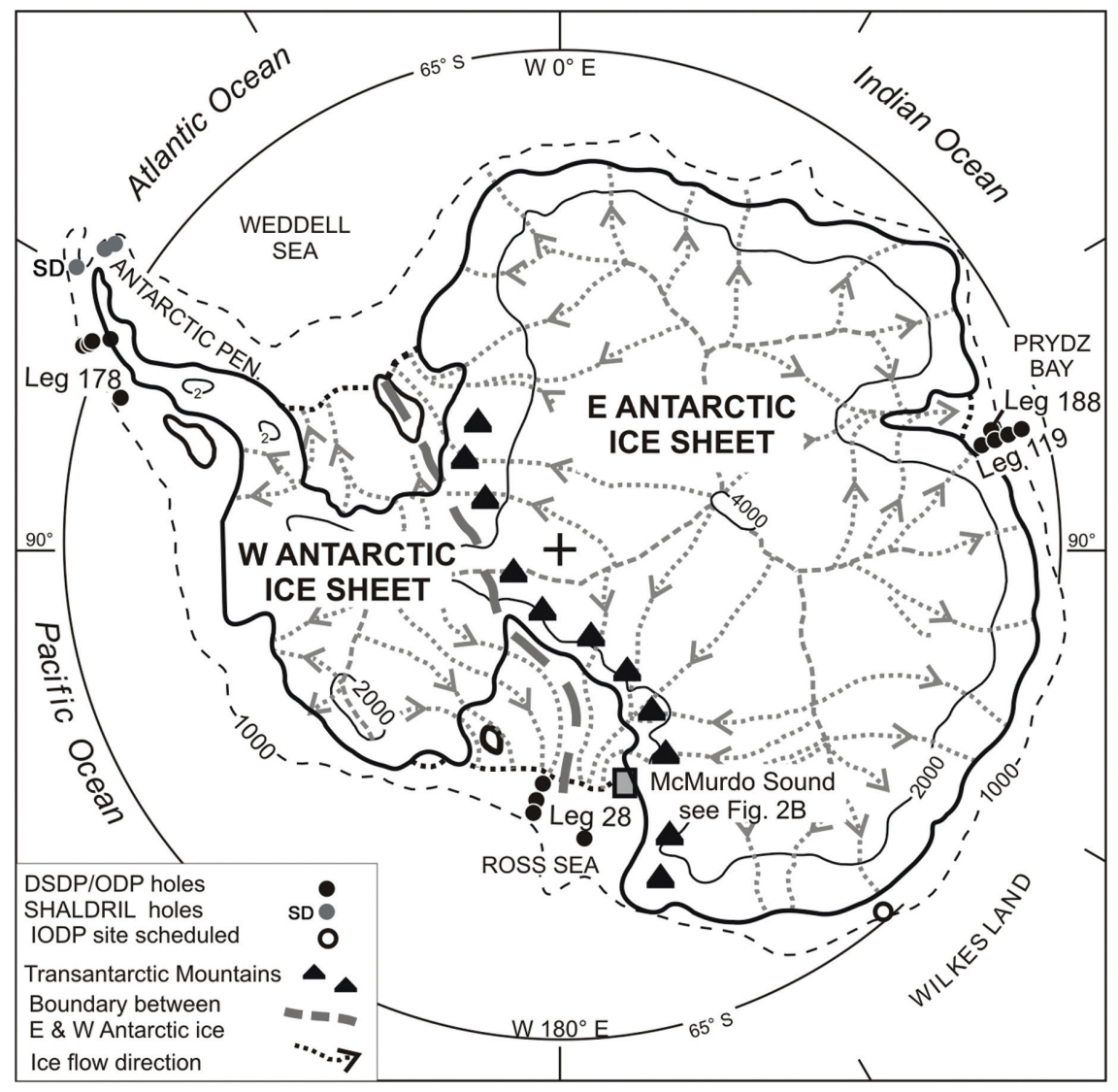

FIGURE 1 Locations of geological drill sites on land and on the Antarctic continental shelf. Details and references are given in Table 1. McMurdo Sound drill sites are shown in Figure 2A. 
The ship-based system had the advantage that it could be deployed at a number of places around the Antarctic margin, but was limited by ice conditions and poor recovery of glacimarine sediments from near-shore shelf basins. Nevertheless, the cores taken have provided useful constraints on the Cenozoic history of the Antarctic ice margin and climate from the Ross Sea, Prydz Bay, and Antarctic Peninsula sectors (Table 1). The land-based system, once adapted for sea ice, had the advantage that it could yield long and continuous core with near-complete recovery. However, it was rather cumbersome and required an ice platform that was firmly tied to land. Although the system has been improved through the MSSTS-1, CIROS, and Cape Roberts Projects (Table 1), continuing to exploit the fast-ice rim around McMurdo Sound as a drilling platform, attractive drilling targets beneath fast sea ice elsewhere on the Antarctic margin have yet to be identified.

The results from both ship-based and sea-ice-based drilling have provided a framework for the Cenozoic history of the Antarctic ice sheet (Kennett and Warnke, 1992, 1993; Barrett, 1999), but more detail has become known for Oligocene and early Miocene times, especially from the $1500 \mathrm{~m}$ of strata cored off Cape Roberts (Naish et al., 2001; Barrett, 2007), than in subsequent times. The first results of the shift from sea-ice- to shelf-ice-based drilling reported below add a great deal to the late Cenozoic story.

\section{THE ANDRILL MCMURDO ICE-SHELF PROJECT}

The aim of the MIS Project was to obtain a continuous sediment core through approximately 1200 m of Neogene ( 0-10 Ma) glacimarine and volcanic sediment that had accumulated in the Windless Bight region of the MIS (Figure 2A). The present-day MIS forms the northwest part of Ross Ice Shelf where it has been pinned by Ross Island for the last $\sim 10 \mathrm{ka}$ (McKay et al., 2007), and is nourished by ice sourced locally and from the East Antarctic ice sheet (EAIS) outlet glaciers in the southern Transantarctic Mountains (TAM). The drill site was situated above a flexural moat basin formed in response to Quaternary volcanic loading of the crust by Ross Island, superimposed on regional subsidence associated with Neogene extension of the Terror Rift (Horgan et al., 2005; Naish et al., 2006) (Figure 2B).

Between October 29 and December 26, 2006, a single 1284.87-m-deep drill core (AND-1B) was recovered from the bathymetric and depocentral axis of the moat in $943 \mathrm{~m}$ of water from an ice-shelf platform. The drilling technology employed a sea-riser system in a similar fashion to the Cape Roberts Project (CRP), but utilized a combination of soft sediment coring in upper soft sediments and continuous wire line diamond-bit coring. Innovative new technology, in the form of a hot-water drill and over-reamer, was used to make an access hole through $85 \mathrm{~m}$ of ice and to keep the riser free during drilling operations.

The MIS project has two key scientific objectives:
1. Provide new knowledge on the late Neogene behavior and variability of the Ross Ice Shelf and Ross Ice Sheet and the West Antarctic ice sheet, and their influence on global climate, sea-level, and ocean circulation.

2. Provide new knowledge on the Neogene tectonic evolution of the West Antarctic Rift System, Transantarctic Mountains, and associated volcanism.

A key outcome of the project will be to provide age control for, and determine the environmental significance of, seismic reflectors that have been mapped regionally within the Victoria Land Basin (Fielding et al., 2007; Henrys et al., 2007) in order to assess the regional impact of global climatic and local tectonic events. A second key outcome of the project will be to use paleoclimatic proxies and boundary conditions to help constrain numerical climate and dynamical ice-sheet models. This paper presents an overview of the MIS Project, and the details are reported in the Initial Results volume (Naish et al., 2007).

\section{TECTONIC AND STRATIGRAPHIC SETTING}

Ross Island lies at the southern end of the Victoria Land Basin (VLB), a 350-km-long, half-graben hinged on its western side at the TAM front (Figure 2). Major rifting in the VLB has occurred since the latest Eocene, perhaps having been initiated in the Cretaceous (Cooper and Davey, 1985; Brancolini et al., 1995), and has accommodated up to $10 \mathrm{~km}$ of sediment. A new rift history, based on the CRP drill cores linked to a new regional seismic stratigraphic framework (Fielding et al., 2007; Henrys et al., 2007), indicates that crustal stretching during the Oligocene synrift phase produced rapid subsidence, followed by thermally controlled slower subsidence in the early Miocene. Renewed rifting within the center of the VLB beginning in the late Miocene has continued through to present day. This forms the Terror Rift (Cooper et al., 1987) and is associated with alkalic igneous intrusions and extrusive volcanism (e.g., Beaufort Island and Ross Island). Quaternary loading of the crust by the Ross Island volcanoes has added significantly to subsidence near Ross Island, and the development of an enclosing moat (Stern et al., 1991). The Terror Rift has accommodated up to $3 \mathrm{~km}$ of Neogene sediment beneath Windless Bight. Here the load-induced subsidence caused by Ross Island has contributed significantly to the generation of accommodation space, especially during the last 2 m.y. (Horgan et al., 2005).

Neogene strata have now been extensively mapped in southern McMurdo Sound from the Drygalski Ice Tongue south to Ross Island. These Neogene strata show a thickening and eastward-dipping succession extending under Ross Island in the vicinity of the MIS Project drill site. Analysis of these strata, which have now been sampled by MIS project drilling, will contribute significantly to the young tectonic history of the West Antarctic Rift System. 

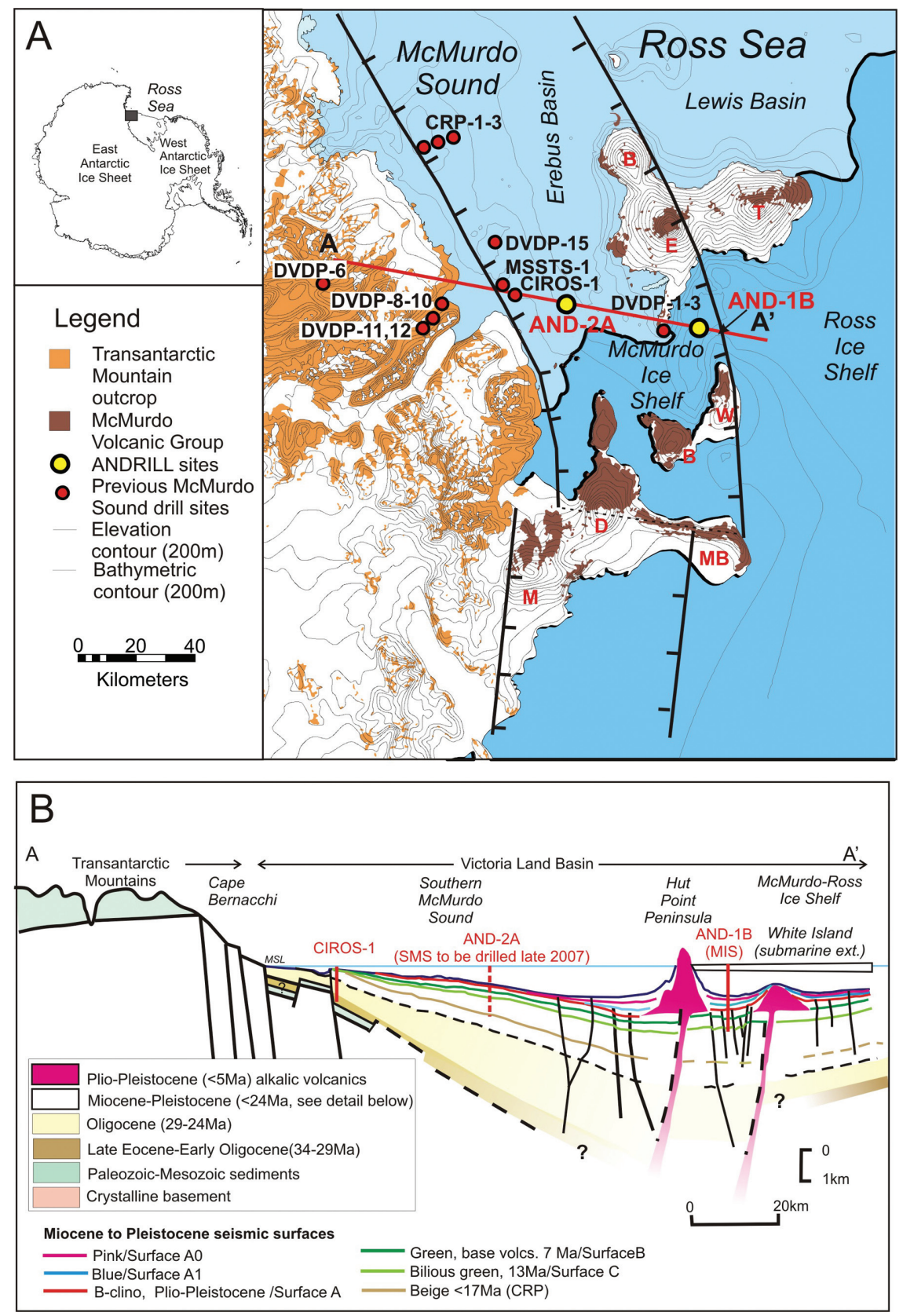

FIGURE 2 (A) Location of key geographical, geological, and tectonic features in southern McMurdo Sound. Volcanic centers of the Erebus Volcanic Province include Mt. Erebus (E), Mt. Terror (T), Mt. Bird (B), White Island (W), Black Island (B), Mt. Discovery (D), Mt. Morning (M), and Minna Bluff (MB). Boundary faults of the southern extension of Terror Rift are also shown. Location of ANDRILL Program drill sites and previous programs (DVDP, CIROS, MSST) are shown. (B) Schematic structural-stratigraphic cross-section across the VLB (located in [A] as "A-A") shows the stratigraphic context of the MIS and SMS drill sites with respect to previous drilling in Southern McMurdo Sound. The cross-section is compiled from interpreted seismic reflection data, previous drill core data from MSSTS-1 and CIROS-1 (Barrett, 1986, 1989), and models for the evolution of the VLB.

\section{CHRONOSTRATIGRAPHY OF “AND-1B”}

A preliminary age model for the upper $700 \mathrm{~m}$ of drill core constructed from diatom biostratigraphy (Scherer et al., 2007) and radiometric ages on volcanic material (Ross et al., 2007) allows a unique correlation of $\sim 70$ percent of the magnetic polarity stratigraphy with the Geomagnetic Polarity Time Scale (Wilson et al., 2007). The age model provides several well-constrained intervals displaying relatively rapid $(<1 \mathrm{~m} / \mathrm{k}$.y.) and continuous accumulation of sediment punctuated by several 0.5 m.y. to 1.0 m.y. stratal hiatuses representing more than half of the last $7 \mathrm{Ma}$. Thus the AND1B record provides several highly resolved "windows" into the development of the Antarctic ice sheets during the late Cenozoic. Strata below $\sim 620 \mathrm{mbsf}$ are late Miocene in age (5-13 m.y.). At the time of writing, the chronostratigraphic data available for this interval include three radiometric ages on volcanic clasts from near $1280 \mathrm{mbsf}$ constraining the age for the base of the AND-1B drill core to $<13.5$ m.y. Work continues to improve the age control on the lower part of the cored interval. 


\section{RELATIONSHIP TO REGIONAL SEISIMIC STRATIGRAPHY}

Prior to drilling the MIS target, five distinctive reflectors marking regional stratal discontinuities had been mapped through a grid of seismic data in the vicinity of the drill site (HPP and MIS lines) (Naish et al., 2006) (Figure 2), and linked to marine seismic reflection data and reflector nomenclature in McMurdo Sound (Fielding et al., 2007). We have used whole-core velocity measurements and VSP first arrival travel-time picks (see Hansaraj et al., 2007; Naish et al., 2007) to derive a time-depth conversion curve to convert the seismic reflection section to depth. We have summarized in Figure 3 and below our correlation of the regional seismic stratigraphy with the AND-1B drill core.
1. $\operatorname{Rg}$ (Surface $\mathbf{C}$, bilious green reflector): This regionally extensive discontinuity is correlated with top of a 60-m-thick interval late Miocene volcanic sandstone (LSU 7) and the base of a 150-m-thick, high-velocity (3000 ms $\left.{ }^{-1}\right)$ interval of diamictite cycles (LSU 6.4). ${ }^{40} \mathrm{Ar} /{ }^{39} \mathrm{Ar}$ dates on ashes beneath $\mathrm{Rg}$ indicate that this discontinuity is $<13.8$ Ma.

2. Rh (Surface B, dark green): This regionally extensive discontinuity is correlated with the base of a 180-m-thick interval of late Miocene-early Pliocene, pyritecemented, high-velocity volcanic sandstone and mudstone (LSU 5). Regionally the green reflector correlates with the base of volcanic bodies in the VLB north of Ross Island. It is also correlated with the base of White Island volcano (Figure 2) dated at $7.6 \mathrm{Ma}$ (Alan Cooper, University of Otago, unpublished data).

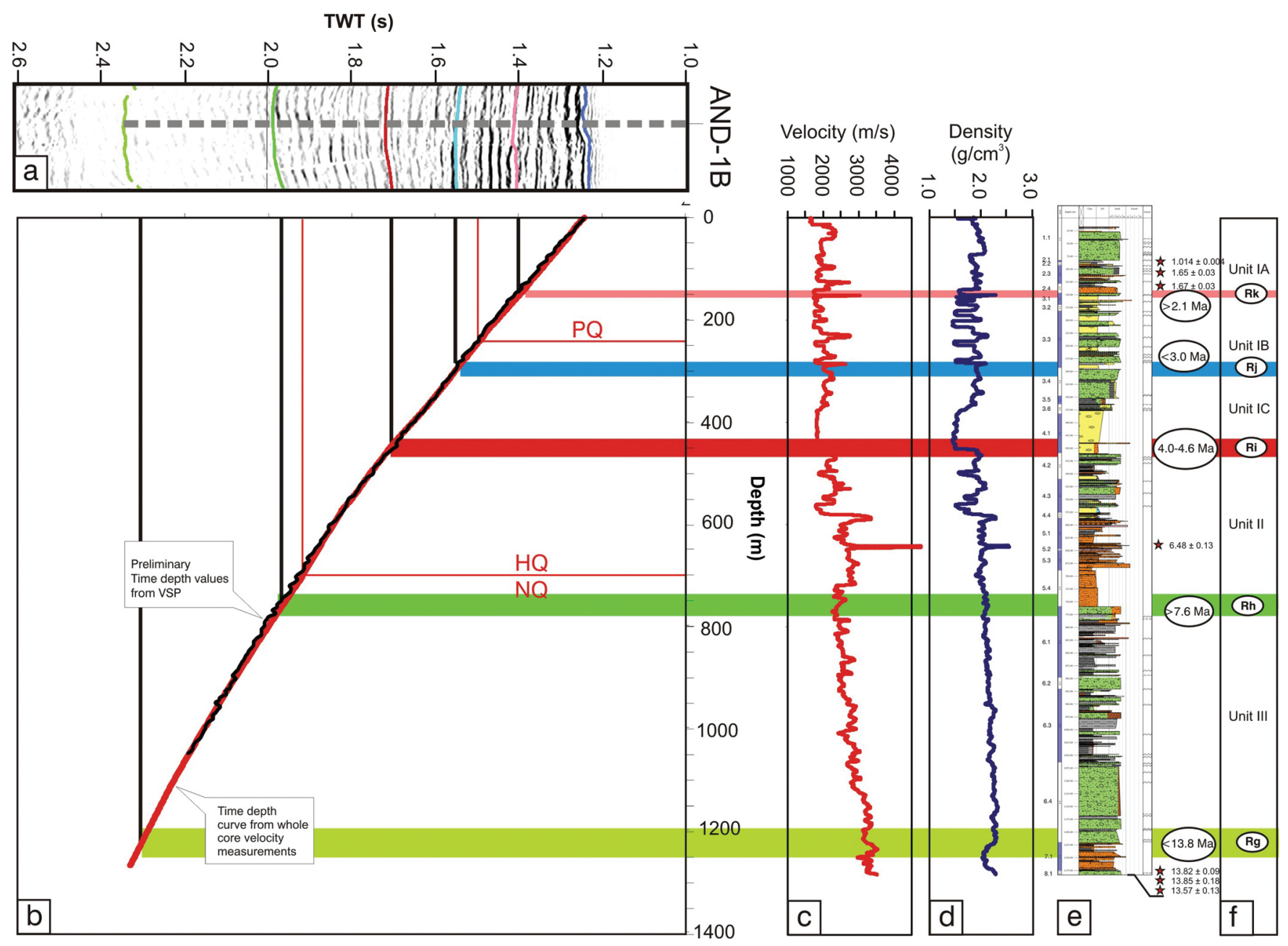

FIGURE 3 Integrated plot correlating seismic reflectors with the lithologic log. We have used the whole-core velocity (c) to derive a time-depth conversion curve (b) together with VSP arrival times to map the seismic reflection profile from MIS-1 (a) to drill hole depth and correlate with core lithologies and lithostratigraphic units (e). Seismic stratigraphic units identified are from the MIS Science Logistics and Implementation Plan (SLIP) (Naish et al., 2006) and have been mapped regionally (Fielding et al., 2007). 
3. Ri (Surface A2, b-clino, red reflector): This regionally extensive reflector marks the base of a $~ 100-\mathrm{m}$ thick seismically opaque interval that separates high-amplitude reflections of the underlying unit. It corresponds with the base of prograding clinoforms north of Ross Island, and locally marks the base of flexure associated with Ross Island volcanic loading (Horgan et al., 2005). In AND-1B, Surface A2 correlates with the boundary between the $~ 90-\mathrm{m}$ thick, low-density, low-velocity $\left(1700 \mathrm{~ms}^{-1}\right)$, early Pliocene diatomite interval (LSU 4.1), and the higher-velocity $(<2500$ $\mathrm{ms}^{-1}$ ) diamictites of LSU 4.2 beneath. Diatom assemblages indicate the age of this surface lies between 5.0 Ma and 4.0 Ma. Regionally this reflector has been traced into western VLB, where it is correlated biostratigraphically in MSSTS-1 to core at about $20 \mathrm{mbsf}$ that yields a Pliocene age of 4.6-4.0 Ma based on diatom microfossils (Naish et al., 2006).

4. $\mathbf{R j}$ (Surface A1, turquoise reflector): This regionally extensive reflector marks the base of a $\sim 150$-m-thick unit of strongly alternating high- and low-amplitude reflections. These dramatic cycles in density and velocity reflect regular alternations between diatomite and diamictite in late Pliocene (LSU 3). The turquoise reflector separates strata above that are younger than $\sim 3.0 \mathrm{Ma}$ and below greater than $\sim 3.5$ Ma.

\section{STRATIGRAPHIC ARCHITECTURE}

The 1285-m-long AND-1B drill core provides the first highresolution, late Neogene record from the Antarctic margin (Figure 4) as well as the first long geological record from under a major ice shelf. Details of the lithostratigraphic subdivision, facies analysis, and sequence stratigraphy are presented in an Initial Results volume (Krissek et al., 2007).

\section{Glacial-Interglacial Cyclostratigraphy}

At the time of writing, 60 unconformity-bounded glacimarine sedimentary cycles, of probable Milankovitch duration have been identified, representing repeated advances and retreats of an ice sheet across the drill site during the late Neogene. Bounding unconformities, glacial surfaces of erosion (GSEs), are typically sharp and planar and mark dislocations between enclosing facies. Facies immediately beneath display a range of intraformational deformation features, including physical mixing of lithologies, clastic intrusions, faulting, and soft-sediment deformation. Facies above these surfaces are typically diamictites and conglomerates, and are interpreted as subglacial tillites or near grounding-line

FIGURE 4 Lithostratigraphy, chronostratigraphy, and sequence stratigraphy of the AND-1B drillcore. Cyclic variations in lithologies reflect periodic fluctuations of the ice margin in western Ross Embayment during the last $13 \mathrm{Ma}$. Sources: $*$ = After Ross et al. (2007); ${ }^{\wedge}=$ After Wilson et al. (2007).

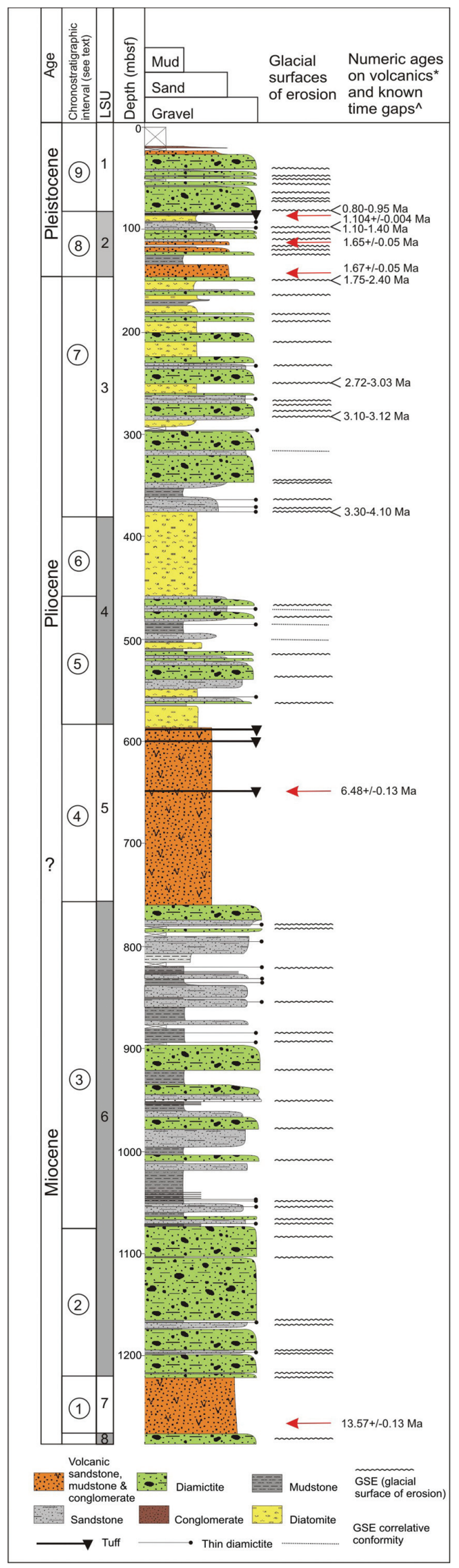


glacimarine deposits. In many cycles the facies succession reflects retreat of the grounding line through ice shelf into open-ocean environments at the interglacial minimum, followed by ice readvance characterized by progressively more glacially influenced facies in the upper parts, culminating in a GSE at the glacial maximum.

\section{Major Chronostratigraphic Intervals and Their Cyclic Character}

Here we summarize the sedimentary succession cored in AND-1B by subdividing it into nine chronostratigraphic intervals largely on the basis of characteristic facies cycles, with their glacial and climatic implications (Figure 4). The latter are addressed in more detail by Powell et al. (2007). Three of the intervals lack cyclicity: interval 1 (a volcanic sandstone), interval 4 (largely volcanic ash), and interval 6 (the 90-m-thick diatomite).

1. Late Miocene volcanic sandstone (1275.24-1220.15 mbsf), LSU 7.

2. Late Miocene diamictite-dominated sedimentary cycles (1220.15-1069.2 mbsf), LSU 6.4.

3. Late Miocene, diamictite/mudstone and sandstone sedimentary cycles (1069.2-759.32 mbsf), LSU 6.1-6.3.

4. Late Miocene-early Pliocene? lapilli tuff, lava flow, and volcanic sandstone and mudstone (759.32-586.45 mbsf), LSU 5.

5. Early Pliocene diamictite/diatomite sedimentary cycles (586.45-459.24 mbsf), LSU 4.2-4.4.

6. Early Pliocene diatomite (459.24-382.98mbsf), LSU 4.1.

7. Late Pliocene diamictite and diatomite sedimentary cycles (459.25-146.79 mbsf), LSU 3.

8. Late Pliocene-early Pleistocene diamictite/volcanic mudstone and sandstone cycles (146.79-82.72 mbsf), LSU 2.

9. Middle-late Pleistocene, diamictite-dominated sedimentary cycles (82.72-0mbsf), LSU 1.

\section{Late-Miocene Diamictite-Dominated Cycles of LSU 6.4 (1220.15-1069.2 mbsf)}

This interval is dominated by thick massive diamictite with thin stratified mudstone interbeds, representing alternations between basal glacial and glacimarine deposition. The diamictites, which form over 90 percent of the interval, contain medium- to high-grade metamorphic basement clasts known from the Byrd Glacier region (Talarico et al., 2007). At this stage we have been conservative in our recognition of grounding-line features in the core that might be used to identify boundaries of the sedimentary cycles. More detailed study is likely to find features such as sets of alternating sharp-based massive and stratified diamictites, representing subglacial and pro-grounding-line environments. The dominance of subglacial deposition and the occurrence of gran- itoid and metamorphic rocks from the Byrd Glacier region imply the long-term existence of a grounded Ross Ice Sheet with short ice-shelf phases, and ice streaming from the southern Transantarctic Mountains. Once a magnetostratigraphy is developed for this section of the core together with new ${ }^{40} \mathrm{Ar} /{ }^{39} \mathrm{Ar}$ ages, further sedimentological and petrographic work should provide an important history of Antarctic ice sheet behavior during the "big" late Miocene, Mi-glaciations of Miller et al. (1991).

\section{Late Miocene, Diamictite/Mudstone-Sandstone Sedimentary Cycles of LSU 6.1-6.3 (1069.2-759.32 mbsf)}

This section is characterized by cycles of subglacial and grounding-line diamictites that pass upward into a glacimarine retreat succession of redeposited conglomerate, sandstone and mudstone. These units are overlain by a more distal hemipelagic terrigenous mudstone with outsize clasts and lonestones. The retreat facies succession is then followed by a proglacial advance facies assemblage in which clast abundance increases together with the occurrence of submarine outwash facies, which is truncated by a glacial surface of erosion. In contrast with the underlying diamictite-dominated interval, over 60 percent of this unit comprises strata representing periods of both ice-shelf cover and open ocean, though still with significant ice rafting, over the drill site. These observations imply a warmer climate for this whole period, and the association increased subglacial meltwater.

\section{Late Miocene-early Pliocene Volcanic Sandstone and Mudstone of LSU 5 (759.32-586.45mbsf)}

This interval is dominated by subaqueously redeposited volcanic sediments, many with near-primary volcanic characteristics. The volcaniclastic sediments are organized into sediment gravity flow deposits (mostly proximal turbidites), indicating a nearby active volcanic center delivering primary volcanic material into a deep basin (several hundred meters water depth). A series of fining upward, altered and degraded pumice lapilli tuffs occur at 623, 603, and 590 mbsf, and a pure fine volcanic glass sand occurs at $577 \mathrm{mbsf}$. All of these have been targeted for argon geochronology. A plagioclase Hawaiite lava with chilled margins and "baked sediments" under its lower contact interrupts the volcanic sediment gravity flows at 646.49-649.30 mbsf, and has been dated by ${ }^{40} \mathrm{Ar} /{ }^{39} \mathrm{Ar}$ at $6.38 \mathrm{Ma}$. The source of this lava and the redeposited volcanic units is thought to be nearby because of the freshness of the glass and angular nature of clasts in the breccias. The unit is virtually devoid of out-size clasts or other features indicative of iceberg rafting or groundingline proximity, suggesting that much of the 120-m-thick interval was deposited rapidly in open water. At this stage we consider this volcanic interval to represent a single eruptive sequence with very high rates of accumulation. 


\section{Early Pliocene Diamictite and Diatomite Sedimentary Cycles of LSU 4.2-4.4 (586.45-459.24 mbsf)}

These cycles can be summarized as comprising, in ascending stratigraphic order: (1) a sharp-based massive diamictite with variable amounts of volcanic glass (subglacial to grounding zone) passing up into (2) stratified diamictite, sandstone, and mudstone with dispersed clasts (grounding-line to distal glacimarine) followed by (3) stratified diatomite (open ocean), which in turn commonly passes up into glacimarine mudstone and sandstone with dispersed clasts (perhaps an indication of an approaching grounding line). The interval that includes the lower part of the diamictite and the underlying glacimarine lithologies is often physically intermixed and displays deformation associated with glacial overriding and shearing but, interestingly, appears to represent little significant erosion by the advance. These cycles show a dramatic change from hemipelagic open-water sedimentation to open-water biogenic sediments (diatomite) at interglacial ice minima.

\section{Early Pliocene Diatomite of LSU 4.1 (459.24-382.98 mbsf)}

This interval is almost solely diatomite, indicating an extended period of high-productivity open water over the site. It is of early Pliocene age ( 4.2 Ma) and is likely to span a period of about 4.2-4.0 m.y., involving a number of glacialinterglacial cycles. The onset of an inferred warmer period is captured in the $10 \mathrm{~m}$ transition beginning at $460 \mathrm{mbsf}$ from a clast-rich to clast-poor muddy diamictite through terrigenous mud to diatomite, with a decline in mud component, outsize clasts, and frequency of $\mathrm{cm}$ - to dm-thick gravity flow deposits. Further research is planned in order to quantify the contemporaneous climate and will involve examination of the terrestrial microfossils and estimation of sea-surface temperatures from geochemical and biological proxies. This diatomite appears to coincide with the widely recognized early Pliocene global warming and accompanying higher sea levels (Dowsett et al., 1999; Ravelo et al., 2004), for which there is evidence elsewhere on the Antarctic margin (e.g., Whitehead et al., 2005). However, well-dated deposits and geomorphological evidence from the adjacent McMurdo Dry Valleys indicate a polar climate persisted there throughout this period (Marchant et al., 1996).

\section{Middle to Late Pliocene Diamictite and Diatomite Sedimentary Cycles of LSU 3 (382.98-146.79 mbsf)}

Within this interval the core is strongly cyclic in nature, and is characterized by 12 glacial-interglacial cycles that is typically composed of a sharp-based lower interval of diamictite in the upper few meters that passes upward into a $\sim 5$ - to 10-m-thick unit of biosiliceous ooze or biosiliceous-bearing mudstone (diatomite). The lower part of diamictites and the upper few meters of diatomites are sheared and deformed, presumably from grounded ice. The transitions from diamic- tite (glacial and glacimarine) to diatomite (open ocean) are dramatic, in many cases occurring in less than a meter of core. Powell et al. (2007) discuss these abrupt facies transitions in terms of rapid retreat of an ice sheet or collapse of an ice shelf. Our preliminary age model suggests that the cycles in this interval may have formed in response to orbital forcing of the ice sheet. This interval will be the focus of further work as we evaluate its significance in terms of the global climatic deterioration coincident with the development of large ice sheets on the northern hemisphere continents (e.g., Shackleton et al., 1984; Maslin et al., 1999).

\section{Late Pliocene-Early Pleistocene Diamictite/Volcanic Mudstone-Sandstone Cycles of LSU2 (146.79-82.72 mbsf)}

This interval displays lithologic alternations between iceproximal facies and open-water volcaniclastic facies. A GSE at 150.90 mbsf is correlated with the Rk-pink reflector and spans as much as $0.7 \mathrm{~m} . \mathrm{y}$. between $2.4 \mathrm{Ma}$ and $1.7 \mathrm{Ma}$. Above this the interval from 146.79 mbsf to $134.48 \mathrm{mbsf}$ represents another glacial-interglacial cycle; that above the diamictite is almost entirely made up of redeposited volcanic (basaltic) sandstone. The sandstone is organized into a series of normally graded turbidites. The interval from $134.48 \mathrm{mbsf}$ to $120 \mathrm{mbsf}$ is characterized by an open-water assemblage of interstratified mudstone and volcanic sandstone that lies stratigraphically above weakly stratified diamictite alternating with sparsely fossiliferous claystone and mudstone, more typical of grounding line and iceberg zone systems. A muddy-sandy volcanic breccia with near-primary volcanic material at $117 \mathrm{mbsf}$ has yielded a preliminary ${ }^{40} \mathrm{Ar} /{ }^{39} \mathrm{Ar}$ age of $\sim 1.6 \mathrm{Ma}$ on basaltic volcanic glass.

A dramatic change upward into massive diamictite from 109.7 mbsf to 97.2 mbsf indicates the return of the ice sheet to the proximity of the drill site. Our preliminary age model suggests that up to $\sim 0.4 \mathrm{~m}$.y., between $1.5 \mathrm{Ma}$ and 1.1 Ma is missing between GSE at $109.7 \mathrm{mbsf}$ and at least 2 GSEs in the overlying interval of amalgamated diamictite above. From 97.2 mbsf to 92.5 mbsf diamictite and volcanic sandstone passes downward into interstratified bioturbated volcanic sandstone and mudstone. The interval from 92.5 mbsf to $86.6 \mathrm{mbsf}$ contains the youngest biosiliceous-bearing sediments in the AND-1B core. The presence of numerous volcaniclastic units and biosiliceous sediments in this interval indicate an extended period of open-water conditions with no sea ice beyond the calving line. An immediately overlying, fining upward lapilli tuff between 85.86 mbsf and $85.27 \mathrm{mbsf}$ has yielded a high-precision ${ }^{40} \mathrm{Ar} /{ }^{39} \mathrm{Ar}$ age on sanidine phenocrysts of 1.01 Ma within a short normal polarity interval interpreted as the Jaramillo Subchron. Thus the underlying biosiliceous interglacial sediments are tentatively correlated with warming during the "super-interglacial" associated with Marine Isotope Stage 31. This interval will be the focus of a future concentrated effort to better characterize the impact of this warm period on ice-sheet behavior. 
Middle-Late Pleistocene, Diamictite-Dominated Sedimentary Cycles of LSU 1 (82-0 mbsf)

Between 83 mbsf and 27 mbsf there are at least 8 cycles of diamictite and thinner bioturbated and stratified intervals of mudstone, volcanic sandstone, and muddy conglomerate. Like the late Miocene diamictite-dominated cycles, the high proportion of subglacial and grounding-line proximal deposits, together with the occurrence of granitoid and metamorphic rocks known from the Byrd Glacier region (Talarico et al., 2007), implies existence of a grounded Ross Ice Sheet in the middle and late Pleistocene. The implied presence of a grounded ice sheet for much of this time is intriguing as it also corresponds with a period of Earth history dominated by $80-120$ ka fluctuations in large Northern Hemisphere ice sheets. Further work will focus on (1) how this ice sheet responded to the late Pleistocene interglacials, which in Antarctic ice-core records indicated polar temperatures warmer than today (EPICA Community, 2004; Jouzel et al., 2007), and (2) the role of orbital forcing on Antarctic ice sheets (e.g., Huybers and Wunsch, 2005; Raymo et al., 2006) in regulating Pleistocene climate.

\section{IMPLICATIONS FOR ANTARCTIC GLACIAL AND CLIMATE HISTORY}

The AND-1B core has the potential to contribute significant new knowledge about the dynamics of the West Antarctic ice sheet (WAIS) and Ross Ice Shelf and Ice Sheet system, as well as contributing to understanding the behavior of the EAIS outlet glaciers during the late Cenozoic. New chronological data will allow certain intervals of the core to be correlated with other proxy climate records (e.g., ice and marine isotope records) and hence the sensitivity of the ice sheet to a range of past global climate changes to be evaluated. The significant results thus far are that the Ross Ice Sheet, fed by WAIS and EAIS outlet glaciers, has undergone significant cyclic variations in extent and timing during the late Neogene. A relatively colder and more stable ice sheet dominated the Ross Embayment in the early late Miocene between $13 \mathrm{Ma}$ and $10 \mathrm{Ma}$, becoming more dynamic in the latest Miocene (9-7 Ma) with subglacial water discharge, still with periodic grounded ice in the Ross Embayment. These conditions were followed by a period around $4 \mathrm{Ma}$ when the Ross Embayment was relatively ice-free, with highly productive, warmer oceanic conditions, followed by a return to cycles of advance and retreat of grounded ice. From middle Pleistocene to Recent the ice sheet is characterized by a change back to more stable, colder conditions. Our preliminary analysis of the more than 25 Pliocene sedimentary cycles indicates significant glacial-interglacial variability, with regular oscillations between subglacial/ice proximal and open-ocean ice distal environments, including extended periods of interglacial warmth when the ice was not calving into the ocean. Our environmental reconstructions to date imply changes in ice-sheet volume that must have contributed significantly to eustasy (e.g., 10-20 m).

Cold early Miocene and Pleistocene till-dominated intervals with clasts originating in the TAM to the south imply that grounded ice from the big outlet glaciers to the south was reaching McMurdo Sound during these times. Today Byrd Glacier-sourced ice in the shelf flows east of Ross Island. Glaciological reconstructions (e.g., Denton and Hughes, 2000) require significant ice volume from WAIS to direct the flow lines of the southern outlet glaciers into the McMurdo region during glacial periods, and also to maintain an ice shelf during ensuing interglacial retreats. Thus, we view the sedimentary cycles representing primarily the expansion and contraction of WAIS in concert with fluctuations in the flow of TAM outlet glaciers. The TAM outlet glaciers alone do not provide enough ice volume to maintain an ice sheet or ice shelf in the Ross Embayment.

Work is planned in the near future to further understand and constrain ice-sheet dynamics, especially during periods of hypothesized global warmth that will provide useful analogues for constraining the behavior of Antarctic ice sheets in the context of future climate change. To achieve this we will integrate our core data-such as clast provenance, biological and geochemical proxies-with the new generation of ice-sheet and climate models.

\section{SUMMARY}

Repetitive vertical successions of facies imply at least 60 fluctuations of probable Milankovitch duration between subglacial, ice-proximal, and ice-distal open marine environments. These have been grouped into three main facies associations that correspond to glacial-interglacial variability during climatically distinct periods of the late Neogene:

1. Cold polar climate with MIS site dominated by grounded ice but some retreat to ice-shelf conditions (late Miocene, 13-10 Ma and Pleistocene, 1-0 Ma).

2. Warmer climate with MIS site dominated by ice-shelf and open-water conditions (hemipelagites), with occasional periods of grounded ice (early-late Miocene, 9-6 Ma).

3. Warmer climate with extended periods of openocean conditions (pelagic diatomites) with periods of sub-ice shelf and grounded ice deposition (Pliocene, 5-2 Ma).

The $~ 90$-m-thick early Pliocene ( 4.2 Ma) interval of diatomite shows no apparent glacial cyclicity and represents an extended period of ice-free conditions indicative of a reduced WAIS. Late Pliocene ( 2.6-2.2 Ma) glacial-interglacial cycles characterized by abrupt alternations between subglacial/ice-proximal facies and open marine diatomites imply significant WAIS volume fluctuations around the time of the early Northern Hemisphere glaciations. A 4-m-thick interval of diatomaceous mudstone in the middle Pleistocene 
also represents similar open-ocean interglacial conditions. The last million years is dominated by deposition from grounded ice with periods of sub-ice-shelf sedimentation like the present day.

\section{ACKNOWLEDGMENTS}

The ANDRILL project is a multinational collaboration of the Antarctic Programs of Germany, Italy, New Zealand, and the United States. Antarctica New Zealand is the project operator and has developed the drilling system in collaboration with Alex Pyne at Victoria University of Wellington and Webster Drilling and Enterprises Ltd. Antarctica New Zealand supported the drilling team at Scott Base and Raytheon Polar Services supported the science team at McMurdo Station and the Crary Science and Engineering Laboratory. Scientific support was provided by the ANDRILL Science Management Office, University of Nebraska-Lincoln. Scientific studies are jointly supported by the U.S. National Science Foundation, NZ Foundation for Research, the Italian Antarctic Research Program, the German Science Foundation, and the Alfred-Wegener-Institute.

\section{REFERENCES}

Anderson, J. B. 1999. Antarctic Marine Geology. Cambridge: Cambridge University Press.

Anderson, J. B., J. Wellner, S. Wise, S. Bohaty, P. Manley, T. Smith, F. Weaver, and D. Kulhanek. 2007. Seismic and chronostratigraphic results from SHALDRIL II, Northwestern Weddell Sea. In Antarctica: A Keystone in a Changing World-Online Proceedings for the Tenth International Symposium on Antarctic Earth Sciences, eds. Cooper, A. K., C. R. Raymond et al., USGS Open-File Report 2007-1047. Short Research Paper 094, doi:10.3133/of2007-1047.srp094.

Barker, P. F., A. Camerlenghi, G. D. Acton et al. 1999. Proc. Ocean Drilling Program, Initial Report 178, http://www-odp.tamu.edu/ publications/178_IR/178TOC.HTM.

Barrett, P. J., ed. 1986. Antarctic Cenozoic history from the MSSTS-1 drill hole, McMurdo Sound, Antarctica. NZ DSIR Bulletin, 237 pp.

Barrett, P. J. ed. 1989. Antarctic Cenozoic history from the CIROS-1 drillhole, McMurdo Sound, Antarctica. NZ DSIR Bulletin, 245 pp.

Barrett, P. J. 1999. Antarctic climate history over the last 100 million years. Terra Antartica 3:53-72.

Barrett, P. J. 2007. Cenozoic climate and sea level history from glacimarine strata off the Victoria Land coast, Cape Roberts Project, Antarctica. In Glacial Processes and Products, eds. M. J. Hambrey, P. Christoffersen, N. F. Glasser, and B. Hubbart. International Association of Sedimentologists Special Publication 39:259-287.

Barrett, P. J., and M. J. Hambrey. 1992. Plio-Pleistocene sedimentation in Ferrar Fiord, Antarctica. Sedimentology 39:109-123.

Barrett, P. J., and S. B. Treves. 1981. Sedimentology and petrology of core from DVDP 15, western McMurdo Sound. In Dry Valley Drilling Project, ed. L. D. McGinnis. Antarctic Research Series 81:281-314. Washington, D.C.: American Geophysical Union.

Barron, J., B. Larsen et al. 1989. Proc. Ocean Drilling Program, Initial Report 119. College Station, TX: Ocean Drilling Program.

Brancolini, G., et al. 1995. Descriptive text for the seismic stratigraphic atlas of the Ross Sea, Antarctica. In Geology and Seismic Stratigraphy of the Antarctic Margin, eds. A. K. Cooper, P. F. Barker, and G. Brancolini, Antarctic Research Series 68:271-286. Washington, D.C.: American Geophysical Union.
Bushnell, V. C., and C. Craddock, eds. 1970. Antarctic Map Folio Series. New York: American Geographical Society, Map 64-29.

Cape Roberts Science Team (CRST). 1998. Initial Report on CRP-3. Terra Antartica 5:1-187.

Cape Roberts Science Team (CRST). 1999. Studies from the Cape Roberts Project, Ross Sea, Antarctica. Initial Report on CRP-2/2A. Terra Antartica 6(with supplement):1-173.

Cape Roberts Science Team (CRST). 2000. Studies from the Cape Roberts Project, Ross Sea, Antarctica. Initial Report on CRP-3. Terra Antartica 7(with supplement):1-209.

Cooper, A. K., and F. J. Davey. 1985. Episodic rifting of the Phanerozoic rocks of the Victoria Land basin, western Ross Sea, Antarctica. Science 229:1085-1087.

Cooper, A. K., F. J. Davey, and J. C. Behrendt. 1987. Seismic stratigraphy and structure of the Victoria Land Basin, Western Ross Sea, Antarctica. In The Antarctic Continental Margin: Geology and Geophysics of the Western Ross Sea, eds. A. K. Cooper and F. J. Davey. Earth Science Series 5B:27-77. Houston, TX: Circum-Pacific Council Energy Mineral Resources.

Denton, G. H., and T. J. Hughes. 2000. Reconstruction of the Ross ice drainage system, Antarctica, at the last glacial maximum. Geografiska Annaler 82:143-166.

Dowsett, H. J., J. A. Barron, R. Z. Poore, R. S. Thompson, T. M. Cronin, S. E. Ishman, and D. A. Willard. 1999. Middle Pliocene Paleoenvironmental Reconstruction: PRISM2. U.S. Geological Survey Open File Report 99-535, http://pubs.usgs.gov/openfile/of99-535/.

EPICA Community Members. 2004. Eight glacial cycles from an Antarctic ice core, Nature 429:623-628.

Fielding, C. R., J. Whittaker, S. A. Henrys, T. J. Wilson, and T. R. Naish. 2007. Seismic facies and stratigraphy of the Cenozoic succession in McMurdo Sound, Antarctica: Implications for tectonic, climatic and glacial history. Palaeogeography, Palaeoclimatology, Palaeoecology. In Antarctica: A Keystone in a Changing World-Online Proceedings for the Tenth International Symposium on Antarctic Earth Sciences, eds. Cooper, A. K., C. R. Raymond et al., USGS Open-File Report 20071047. Short Research Paper 090, doi:10.3133/of2007-1047.srp090.

Flint, R. F. 1971. Glacial and Quaternary Geology. New York: Wiley.

Hansaraj, D., S. A. Henrys, T. R. Naish, and ANDRILL MIS-Science Team. 2007. McMurdo Ice Shelf seismic reflection data and correlation to the AND-1B drill hole. In Antarctica: A Keystone in a Changing World -Online Proceedings for the Tenth International Symposium on Antarctic Earth Sciences, eds. Cooper, A. K., C. R. Raymond et al., USGS Open-File Report 2007-1047, Extended Abstract 101, http://pubs.usgs. gov/of/2007/1047/.

Hayes, D. E., L. A. Frakes et al. 1975. Initial Reports of the Deep Sea Drilling Project, vol. 28. Washington, D.C.: U.S. Government Printing Office.

Hays, J. D., J. Imbrie, and N. J. Shackleton. 1976. Variations in the earth's orbit: Pacemaker of the ages. Science 194:1121-1132.

Henrys, S. A., T. J. Wilson, J. M. Whittaker, C. R. Fielding, J. M. Hall, and T. Naish. 2007. Tectonic history of mid-Miocene to present southern Victoria Land Basin, inferred from seismic stratigraphy in McMurdo Sound, Antarctica. In Antarctica: A Keystone in a Changing World-Online Proceedings for the Tenth International Symposium on Antarctic Earth Sciences, eds. Cooper, A. K., C. R. Raymond et al., USGS Open-File Report 2007-10477, Short Research Paper 049, doi:10.3133/of2007-1047.srp049.

Horgan, H., T. Naish, S. Bannister, N. Balfour, and G. Wilson. 2005. Seismic stratigraphy of the Ross Island flexural moat under the McMurdo-Ross Ice Shelf, Antarctica, and a prognosis for stratigraphic drilling. Global Planetary Change 45:83-97.

Huybers, P., and C. Wunsch. 2005. Obliquity pacing of the late Pleistocene glacial terminations. Nature 434:491-494.

Jouzel, J., et al. 2007. Orbital and Millennial Climate variability over the past 800,000 years. Science 317:793-796 
Kennett, J. P., and D. A. Warnke, eds. 1992. The Antarctic Paleoenvironment: A Perspective on Global Change, Part 1. Antarctic Research Series, vol. 56. Washington, D.C.: American Geophysical Union.

Kennett, J. P., and D. A. Warnke, eds. 1993. The Antarctic Paleoenvironment: A Perspective on Global Change, Part 2. Antarctic Research Series, vol. 60. Washington, D.C.: American Geophysical Union.

Kennett, J. P., R. E. Houtz et al. 1974. Initial Reports of the Deep Sea Drilling Project, vol. 29. Washington, D.C.: U.S. Government Printing Office.

Krissek, L. A., G. Browne, L. Carter, E. Cowan, G. Dunbar, R. McKay, T. Naish, R. Powell, J. Reed, T. Wilch, and the ANDRILL-MIS Science Team. 2007. Sedimentology and stratigraphy of the ANDRILL McMurdo Ice Shelf (AND-1B) core. In Antarctica: A Keystone in a Changing World - Online Proceedings for the Tenth International Symposium on Antarctic Earth Sciences, eds. Cooper, A. K., C. R. Raymond et al., USGS Open-File Report 2007-1047, Extended Abstract 148, http://pubs.usgs.gov/of/2007/1047/.

Kyle, P. R. 1981. Geological history of Hut Point Peninsula as inferred from DVDP 1, 2 and 3 drill cores and surface mapping. In Dry Valley Drilling Project, ed. L. D. McGinnis. Antarctic Research Series 81:427-445. Washington, D.C.: American Geophysical Union.

Marchant, D. R., G. H. Denton, C. C. Swisher, III, and N. Potter, Jr. 1996. Late Cenozoic Antarctic paleoclimate reconstructed from volcanic ashes in the Dry Valleys region of southern Victoria Land. Geological Society of America Bulletin 108:181-194.

Maslin, M. A., Z. Li, M.-F. Loutre, and A. Berger. 1999. The contribution of orbital forcing to the progressive intensification of Northern Hemisphere glaciation. Quaternary Science Reviews 17:411-426.

McKay, R., Dunbar, G., Naish, T. R., Barrett, P., Carter, L., Harper, M. 2007. Retreat of the Ross Ice Shelf since the Last Glacial Maximum derived from sediment cores in deep basins surrounding Ross Island. Paleoclimatology, Paleogeography, Paleoecology. A Sediment Model and Retreat History for the Ross Ice (Sheet) Shelf in the Western Ross Sea Since the Last Glacial Maximum. In Antarctica: A Keystone in a Changing World-Online Proceedings for the Tenth International Symposium on Antarctic Earth Sciences, eds. Cooper, A. K., C. R. Raymond et al., USGS Open-File Report 2007-1047, Extended Abstract 159, http://pubs. usgs.gov/of/2007/1047/.

Miller, K. G., J. D. Wright, and R. G. Fairbanks. 1991. Unlocking the ice house: Oligocene-Miocene oxygen isotopes, eustasy, and margin erosion. Journal of Geophysical Research 96:6829-6848.

Naish, T. R., et al. 2001. Orbitally induced oscillations in the East Antarctic ice sheet at the Oligocene/Miocene boundary. Nature 413:719-723.

Naish, T. R., R. H. Levy, R. D. Powell, and the ANDRILL MIS Science and Operations Teams. 2006. ANDRILL McMurdo Ice Shelf Scientific Logistical Implementation Plan. ANDRILL Contribution No. 7. Lincoln: University of Nebraska-Lincoln.

Naish, T. R., R. D. Powell, R. H. Levy, and the ANDRILL-MIS Science Team. 2007. Initial science results from AND-B, ANDRILL McMurdo Ice Shelf Project, Antarctica. Terra Antartica 14(2).

O’Brien, P. E., A. K. Cooper, C. Richter et al. 2001. Proc. Ocean Drilling Program, Initial Report 188, http://www-odp.tamu.edu/ publications/188_IR/188ir.htm.

Powell, R. D. 1981. Sedimentation conditions in Taylor Valley inferred from textural analyses of DVDP cores. In Dry Valley Drilling Project, ed. L. D. McGinnis. Antarctic Research Series 81:331-350. Washington, D.C.: American Geophysical Union.
Powell, R. D., T. R. Naish, L. A. Krissek, G. H. Browne, L. Carter, E. A. Cowan, G. B. Dunbar, R. M. McKay, T. I. Wilch, and the ANDRILL-MIS Science team. 2007. Antarctic ice sheet dynamics from evidence in the ANDRILL-McMurdo Ice Shelf Project drillcore (AND-1B). In Antarctica: A Keystone in a Changing World - Online Proceedings for the Tenth International Symposium on Antarctic Earth Sciences, eds. Cooper, A. K., C. R. Raymond et al., USGS Open-File Report 2007-1047, Extended Abstract 201, http://pubs.usgs.gov/of/2007/1047/.

Ravelo, A. C., D. H. Andreasen, L. Mitchell, A. O. Lyle, and M. W. Wara. 2004. Regional climate shifts caused by gradual global cooling in the Pliocene epoch. Nature 429:263-267.

Raymo, M. E., L. E. Lisecki, and K. H. Nisancioglu. 2006. Plio-Pleistocene ice volume, Antarctic climate, and the global $\delta^{18} \mathrm{O}$ record. Science 313:492-495.

Ross, J., W. C. McIntosh, and N. W. Dunbar. 2007. Preliminary ${ }^{40} \mathrm{Ar} /{ }^{39} \mathrm{Ar}$ results from the AND-1B core. In Antarctica: A Keystone in a Changing World-Online Proceedings for the Tenth International Symposium on Antarctic Earth Sciences, eds. Cooper, A. K., C. R. Raymond et al., USGS Open-File Report 2007-1047, Extended Abstract 093, http://pubs. usgs.gov/of/2007/1047/.

Scherer, R., D. Winter, C. Sjunneskog, and P. Maffioli. 2007. The diatom record of the ANDRILL-McMurdo Ice Shelf project drillcore. In Antarctica: A Keystone in a Changing World-Online Proceedings for the Tenth International Symposium on Antarctic Earth Sciences, eds. Cooper, A. K., C. R. Raymond et al., USGS Open-File Report 20071047, Extended Abstract 171, http://pubs.usgs.gov/of/2007/1047/.

Shackleton, N. J., and J. P. Kennett. 1974. Paleotemperature history of the Cenozoic and the initiation of Antarctic glaciation: Oxygen and Carbon isotope analyses in DSDP Sites 277, 279 and 281. In Initial Reports of the Deep Sea Drilling Project, vol. 29, eds. J. P. Kennett, R. E. Houtz et al., pp. 743-756. Washington, D.C.: U.S. Government Printing Office.

Shackleton, N. J., et al. 1984. Oxygen isotope calibration of the onset of ice-rafting and history of glaciation in the North Atlantic region. Nature 307:620-623.

Smith, P. M. 1981. The role of the Dry Valley Drilling Project in Antarctic and international science policy. In Dry Valley Drilling Project, ed. L. D. McGinnis. Antarctic Research Series 81:1-5. Washington, D.C.: American Geophysical Union.

Stern, T. A., F. J. Davey, and G. Delisle. 1991. Lithospheric flexure induced by the load of the Ross Archipelago, southern Victoria Land, Antarctica. In Geological Evolution of Antarctica eds. M. R. A. Thomson, A. Crame, and J. W. Thomson, pp. 323-328. Cambridge: Cambridge University Press.

Talarico, F., et al. 2007. Clast provenance and variability in MIS (AND-1B) core and their implications for the paleoclimatic evolution recorded in the Windless Bight, southern McMurdo Sound area (Antarctica). In Antarctica: A Keystone in a Changing World-Online Proceedings for the Tenth International Symposium on Antarctic Earth Sciences, eds. Cooper, A. K., C. R. Raymond et al., USGS Open-File Report 20071047, Extended Abstract 118, http://pubs.usgs.gov/of/2007/1047/.

Whitehead, J. M., S. Wotherspoon, and S. M. Bohaty. 2005. Minimal Antarctic sea ice during the Pliocene. Geology 33:137-140.

Wilson, G. S., et al. 2007. Preliminary chronostratigraphy for the upper $700 \mathrm{~m}$ (late Miocene-Pleistocene) of the AND-1B drillcore recovered from beneath the McMurdo Ice Shelf, Antarctica. In Antarctica: A Keystone in a Changing World-Online Proceedings for the Tenth International Symposium on Antarctic Earth Sciences, eds. Cooper, A. K., C. R. Raymond et al., USGS Open-File Report 2007-1047, Extended Abstract 092, http://pubs.usgs.gov/of/2007/1047/. 